\title{
A Primer on Exporting to Venezuela ${ }^{1}$
}

\author{
Christina D. Storz, Timothy G. Taylor, and Gary F. Fairchild ${ }^{2}$
}

\section{Introduction}

Every year the U.S. Department of State publishes extensive Country Commercial Guides for a large number of countries. These guides provide a great deal of information useful to individuals interested in developing export markets either through direct exports or through direct foreign investment. This paper provides an abridged version of the Country Commercial Guide for Venezuela as well as supplemental information of direct relevance to agribusiness firms. It is hoped that the information contained in this report provides a useful starting point for individuals interested in exploring export or investment opportunities in Venezuela.

Note: County Commercial Guides are available for U.S. exporters from the National Trade Data Bank's CD-ROM or via the Internet. Please contact Stat-USA by telephone (1-800) STAT-USA for more information. Country Commercial Guides can be accessed via the World Wide Web at http://www.stat-usa.gov, http://www.state.gov, and http://www.mac.doc.gov. They can also be ordered as a hard copy or on diskette from the National Technical Information Service (NTIS) by telephone (1-800) 553-NTIS. American exporters seeking general export information/assistance and country-specific commercial information should contact the U.S. Department of Commerce, Trade Information Center by telephone (1-800) USA-TRADE; or by fax (202) 482-4473.

\section{Economic and Political Overview}

Historically, Venezuela has been a major trading partner of the United States as Venezuelans have traditionally preferred U.S. products and services and, current economic and political uncertainties aside, we expect that the United States will remain an important trading partner.

As Venezuela struggles to maintain its position in the international energy market there may be opportunities for U.S. energy-related companies. Venezuela's untapped natural gas reserves are estimated as the eighth largest in the world and the government of Venezuela is promoting greater use of natural gas domestically as a clean and cost efficient energy source. For Venezuela to reduce its dependency on this single sector, there must be considerable investment in technology and production to expand existing markets and develop new industries.

In 2002, the Venezuelan economy decreased $8.9 \%$. A confluence of events and government

1. This is EDIS document FE525, a publication of the Department of Food and Resource Economics, Florida Cooperative Extension Service, Institute of Food and Agricultural Sciences, University of Florida, Gainesville, FL. Published February 2005. Please visit the EDIS website at http://edis.ifas.ufl.edu.

2. Christina D. Storz, Research Assistant; Timothy G. Taylor, Professor; and Gary F. Fairchild, Professor, Department of Food and Resource Economics, Florida Cooperative Extension Service, Institute of Food and Agricultural Sciences, University of Florida, Gainesville, FL. 
policies contributed to the contraction. Among the causes were a decline in petroleum production, following OPEC quota reductions; a general strike in December of 2002 that affected virtually every economic sector, especially oil production; a dearth of direct private investments because of uncertainty about the political and economic environment; high nominal and real interest rates; and high rates of currency devaluation and domestic inflation.

Venezuela's private sector remains largely on the sidelines, with little domestic investment and a steady loss of jobs and productive capacity. The Venezuelan economy remains highly dependent on its petroleum sector; consequently, any decrease in oil prices will have a significant negative impact on economic growth.

American exports to Venezuela were US\$4.5 billion in 2002, decreasing to US\$2.5 billion in 2003 due countrywide strike, $23 \%$ unemployment, and an inflation rate of about $35 \%$. To exacerbate this situation, Venezuelan authorities placed a ban on foreign exchange transactions on January 22, 2003, and created the Commission for the Administration of Foreign Currency (CADIVI).

Most macroeconomic indicators in 2003 showed a deepening recession, with some at historically poor levels. In the near term, an economic recovery depends on continued strong oil prices and an increase in the country's oil production capacity.

Political uncertainty amidst a highly polarized atmosphere has increased investors' doubts about the economy. The government has been covering its financial needs through the internal market, the monetization of the Central Bank profits, external debt, and withdrawals from the Investment Fund for Macroeconomic Stabilization (FIEM).

The exchange controls imposed in February of 2003 are expected to continue in the short term in some fashion. These controls have introduced some distortions in the economy, including an accumulation of excess liquidity, fewer fiscal expenditures and delays in mandatory central government payments, and the development of an unofficial parallel exchange market with an exchange rate of more than $60 \%$ over the official rate. Most private companies have problems paying for imports with some forced to reduce their operations or even close them. The reduction in imports has contributed to an increase in the unemployment rate to approximately $23 \%$.

For many years, Venezuela had consistently placed among the top U.S. export markets (approximately US $\$ 6$ billion in 2001). Venezuela's need for capital goods, particularly in the energy sector, led to year-on-year increases until 2002. American exports to Venezuela decreased to US\$4.5 billion in 2002 and US $\$ 2.5$ billion for 2003. The latter figure arises from the massive reductions in imports due to currency controls and a slump in general demand.

American investors should carefully examine opportunities and projects on a case-by-case basis and in particular the method of payment. Appointing a local agent or consultant is essential, even if only to stay informed of changes and potential projects. It is also strongly advised to seek appropriate legal advice on how to set up business in Venezuela and to monitor changes in legislation that may affect foreign investment and sales in certain sectors.

The most important near-term growth prospects remain in the extractive and infrastructure-related areas. The growth industries include petroleum (production, refining, and marketing) and other hydrocarbons, mining, telecommunications, and power generation.

\section{Marketing U.S. Products and Services}

There are a number of factors that should be considered in exporting products to Venezuela. This section provides a brief overview of many critical factors that must be considered.

\section{Establishing a Business}

A business must first be registered with the Venezuelan Municipal "Commercial Registry" to be legally established. The opening and operating of a coordinating or reporting office is not considered foreign investment or a business activity as long as the office does not sell and is being financed from the home office. Any other more detailed activity would 
fall under the Commercial Code. Business enterprises can be registered as corporations, as limited liability companies, as partnerships, or as sole proprietorships.

It is advisable to have a local attorney draft the registration documents. Registration itself is fast and inexpensive. After that, a municipal business license has to be obtained, which also requires the payment of a small quarterly tax. The final step is to obtain the income tax registration number (RIF) from the Ministry of Finance. The RIF must be shown on all fiscal documents and bills and serves generally as an identification number for the entity.

Venezuela benefited from several USDA programs that assist U.S. agricultural exports. The primary such program is the Export Credit Guarantee Program (GSM-102). This provides coverage of commercial credits extended to finance exports for credit periods up to three years. The program provided for coverage of up to US $\$ 450$ million for U.S. exports to the Andean Region (including Venezuela) of wheat, feed grains, oilseeds, oil meals, and other products. The program is currently suspended for Venezuelan bankers due to the imposition of exchange controls. The credit guarantee line is still available for Venezuela through CAF.

\section{Distribution / Sales Channels}

There are no existing laws or regulations that limit distribution. All channels are possible: manufacturer's representative or commissioned agent, wholesale importing distributor, importing retailer, or direct sale to end-user. It is quite common to find Venezuelan companies undertaking several of these functions simultaneously. No specific business license is required for a local company or individual to be an importer. Many retailers administer their own imports, sometimes placing orders through commissioned agents or purchasing directly from foreign suppliers.

Government agencies usually require that a seller of specific types of equipment be an authorized seller for the foreign manufacturer; multiple bids by the same manufacturer may result in disqualification. Authorization to resell is especially important where after-sale support might be needed.

\section{Agents / Distributors: Finding a Partner}

A commissioned sales agent or manufacturer's representative finds customers, passes the order to the foreign company, and receives a commission on the sale. The amount of commission will vary between $5 \%$ and $30 \%$, depending on the nature of the product and the amount of work or time required by the agent. The use of agents where there are multiple levels of customers may be the most practical and efficient means of covering the market. Wholesalers or stocking distributors often have minimal outside sales forces, relying on advertising and on walk-in customers or buyers. Distributors may be important where there is strong after-sale support needed for the product. Venezuelan companies at any step in the distribution chain tend to place repeated small orders. Foreign company requirements as to minimum orders, or even minimum annual sales, may meet with strong resistance from prospective distributors or agents.

There are numerous ways to find a business partner. The various US\&FCS services, such as the International Partner Search, Gold Key Service, Video Gold Key Service, contact lists (screened/unscreened), trade missions, catalog shows, and USDOC-certified trade shows, are commonly used. A web-based service (e.g., BuyUSA.com) can also assist in helping companies find agents. However, no service or list of potential leads can replace a visit to the country to study and interview prospects. Venezuela has no set of laws or regulations that protect a local agent. Regardless of the requirements for written agreements, there are no legally binding indemnification requirements. The written agreement in all principal-agents, supplier-distributors arrangements is binding. It is common practice to have medium-term trial agreements with clear performance objectives when entering new business relationships.

On the other hand, placing a Venezuelan citizen on the company payroll can be costly in case of separation, which would entitle him to all benefits of the very generous labor laws. Absent unusual circumstances, commissioned agents are not considered employees. 


\section{Direct Marketing}

Marketing, through TV commercials, newspaper inserts, house visits, or street vendors is common. Mail orders are not an option because of the low reliability of the postal system. Placing orders by phone with delivery by messenger is becoming popular, and several such companies have been successful by placing their catalogs in newspapers as weekend-issue inserts. As the telephone system continues to improve, direct marketing by phone will become more common. Almost all businesses now use fax machines in their day-to-day business and many utilize e-mail. E-commerce is in the very early stages, and could be a promising area for growth.

\section{Franchising}

Franchising is allowed under the existing foreign investment laws. Franchise payments, royalties, patent, or technical assistance agreements must be registered, but are not subject to re-negotiation or other controls, with the Superintendent of Foreign Investment (SIEX). Certain payments for the use of franchised rights may be subject to withholding taxes. Decree 2095 guarantees the ability to remit funds for franchising rights.

From a marketing standpoint franchises will most likely only be successful if they bring technology, services or systems that are not generally available in the country. Franchising currently provides some of the best investment opportunities.

\section{Joint Ventures / Licensing}

Joint ventures formed by establishing a new company with local and foreign capital or by buying into an existing local company are quite common. The only requirement is registration of the venture with SIEX. The law imposes no limit on the amount of dividends, reinvestment, or repatriation. Similarly, manufacturing under license is permitted, but to pay license fees, royalties, or trademark and patent fees the license must first be registered with SIEX.

Joint ventures and wholly-owned subsidiaries of foreign companies are treated the same as Venezuelan firms. Such enterprises as security companies, television and radio broadcasting, and the publication of Spanish-language newspapers are restricted from foreign investment of more than $20 \%$ of the capital. Professional services are also restricted, falling under the Law of Professions. Banking, insurance and brokerage services and companies have recently been opened to foreign investment.

\section{Selling Factors / Techniques}

American companies often make the mistake of providing sales literature in English when selling to their agents or distributors. While many businessmen speak English, much of their staff and customers will not. Consequently, failure to prepare materials in Spanish eliminates a key-selling tool.

In most cases, support has to be given to new agents or distributors in the form of technical information on applications, especially if a product is new or entails new technologies. The average Venezuelan business does not have sales engineers or specialists, so some form of training is required. The same situation exists for maintenance or repair technicians; agents might request that personnel be trained in the United States. Venezuelan end-users of any type of machinery or equipment require that spare parts, repair service, and after-sale support be available. Sales at the retail level are not much different from those in the United States. Price haggling in established stores is not common. Special offers are frequent, but are specifically seasonal in nature. There are numerous malls, but few department stores.

\section{Advertising / Trade Promotion}

While there are some specialized publications, daily newspapers are the most common forms of advertising. Television and radio commercials are used heavily to promote durable and non-durable consumer goods. Billboards are common, as are leaflets, newspaper inserts, and in-store promotions. There are numerous advertising agencies, some being subsidiaries of well-known U.S. companies.

There are many trade shows and expositions, some organized on behalf of trade or industrial associations by capable local show organizers. American companies also have organized trade shows 
in Venezuela directly. Normally they are widely advertised and, even if specialized, visited by the public in general. These shows have proven to be an excellent vehicle to promote a new product, or to find an agent or distributor.

\section{Product Pricing}

Price controls and/or mark-up limits have existed in Venezuela for many years. Otherwise, pricing is left to the market; mark-ups of $100 \%$ or more between producers or importer and retailer have been rather common. The law prohibits price fixing among manufacturers. All promotions require registration and authorization by the consumer protection agency INDECU.

\section{Selling to the Government}

The purchase of goods and services by government agencies is ruled by a complex system of laws, decrees, and regulations. Venezuelan government officials are not permitted to conduct official business in any language except Spanish. There is no specific Venezuelan agency in charge of government procurement or which provides guidance to foreign bidders or sellers. The purchasing agency within the government unit buying the goods or services may be the best source of assistance, especially to foreign companies with no previous experience in Venezuela.

Anyone wanting to sell to a Venezuelan governmental agency must be registered in the National Register of Contractors, which is maintained by the Central Office of Statistics and Informatics. This National Register can open sub-registers, normally found in all ministries and governmental agencies that regularly purchase goods or services.

\section{Need for a Local Attorney}

Contracting a reputable local law firm is advisable for any U.S. company wishing to establish a presence in Venezuela, form joint ventures, register a trademark, or enter into any type of business relationship. Local attorneys can provide essential start-up information on labor laws, tax regulations, purchase of real estate, and drafting by-laws of the local subsidiary. Venezuelan laws are complicated, even more so since many activities are regulated, not only by laws, but also by presidential decrees or specific regulations. The bureaucracy and paperwork are often complicated. A number of large law firms have attorneys who have also studied in the United States and are familiar with matching a U.S. company's requirements to the local law. A list of Venezuelan law firms, which specialize in various aspects of commercial and investment law, can be requested from the U.S. Embassy in Caracas.

\section{Agribusiness Industry Prospects}

The U.S. share of the Venezuelan food and agricultural market has been eroding over the past decade, falling to just over $30 \%$ of Venezuela's agricultural imports in recent years. The United States faces increasingly face tough competition from emerging suppliers (e.g., Argentina, Brazil, and Colombia) that have established preferential trade agreements throughout South America. In 1997, Venezuela was the leading overall agricultural market in South America for the United States; today, it is the second largest market for our products, after Colombia.

Major problems with currency controls have hit all exporters hard, particularly Colombia, the second largest food supplier to the Venezuelan market. The large U.S. companies are better positioned to weather the storm; U.S. products are gaining increased market share, but of a much smaller market.

American sales of bulk commodities to Venezuela have leveled off in recent years, but rice and soybean meal shipments could push sales higher. A strong consumer preference exists for practically anything associated with the United States, which gives an advantage to many U.S. food products. Value-added, consumer-ready imports had been the fastest growing sector for U.S. agricultural exports to Venezuela, topping US\$100 million in 2001, but government import restrictions have hurt this sector the most.

Potential growth is cloudy at this time because non-tariff trade barriers (e.g., restrictive use of licenses and phytosanitary permits) have become a major impediment to trade for basic food products. 
However, this 25 million-person market will remain an attractive destination for many food exporters (fax 58-313-975-7615; e-mail AgCaracas@fas.usda.gov).

The following is an illustrative list of traditional, as well as emerging export opportunities for U.S. agricultural products to Venezuela:

\section{Corn}

Venezuela mainly produces white corn for human consumption, but due to the recession, we expect domestic consumption of white corn to drop slightly, even though precooked corn flour is a staple component of the Venezuelan diet. Yellow corn is imported and traditionally goes to the feed sector, which has been severely battered by restrictions on imports in recent years. Meat producers are now arguing that price controls on pork and poultry are too low to cover their cost of inputs, and may lead to a $20 \%$ to $30 \%$ reduction in operations. Demand for poultry and pork is also expected to drop due to the harsh economic situation. Both feed-use and human-use estimates for corn were expected to improve in 2004 as the economic situation stabilizes.

Imports of yellow corn are subject to Venezuela's import licenses regime for corn and sorghum. Proof of domestic sorghum and/or white corn purchases are required in order to obtain corn import permits. Certification issued by the Venezuelan Agricultural Board of Trade, BOLPRIAVEN, is now mandatory to demonstrate proof of grain purchases.

\section{Wheat}

Venezuela produces almost no wheat, but consumes large quantities of bread, crackers, pastries, and pasta (Venezuela is the second highest per capita consumer of pasta in the world). Wheat for these products must be imported. The United States is a natural supplier due to its proximity and the year-around availability of several wheat varieties. Despite these advantages, the United States faces stiff competition in this market from suppliers such as Canada whose prices are sometimes lower than U.S. prices.
Wheat consumption should not drop significantly because pasta and bread constitute low-cost basic staples of the Venezuelan diet, but recent price controls have set bread and pasta prices at relatively higher levels, which is consistent with the government's policy of promoting corn and rice consumption. The government has shown an open policy toward wheat imports. For example, it declared that there would not be any restrictions on the issuance of import licenses for 2003. Wheat is included among the high priority products to receive dollars under the currency controls, although there have been delays in issuance of foreign exchange.

\section{Rice}

Venezuela has been self-sufficient in rice production in recent years but, due to the impact of a three-year drought in the major irrigated production area, rice imports were needed in 2003 and 2004 to avoid a drop in availability and a run-up in prices. Rice imports numbered over 120,000 tons in 2003. The government has been trying to stimulate rice consumption as an alternative to wheat- and corn-based products, but with the current production shortfalls and the drop in consumer purchasing power, consumption of all products is expected to decline. At the recently set internal price control, domestic rice is currently below market prices in Colombia, and it is estimated that some product is moving across the border in contraband or "green" channels. Rice imports could occur in either paddy or milled form since there is a sophisticated milling industry in the country. The government will need to allocate both foreign exchange and import permits to allow the rice trade to occur.

\section{Soybeans}

The majority of Venezuela's oilseed needs are supplied by imports since domestic soybean and African palm oil production has not taken off as expected. Soybeans are the principal oilseed consumed in Venezuela and they are mostly all imported. In recent years, Bolivia has become the major supplier of soybeans, followed by Brazil and Argentina, due to tariff preferences.

Venezuela is a member of the Andean Community, along with Colombia, Ecuador, Bolivia, 
and Peru. Pact members have negotiated common external tariffs, and utilize the Andean Community agricultural price band system to determine tariff rates. This system applies variable ad valorem tariffs to certain agricultural imports from countries other than those of the Andean Community, and is designed to raise tariffs when world prices are low and to lower tariffs when world prices are high. Oilseeds and oilseed products are included in the price band system. Check online for the most current tariff rates (http://www.comunidadandian.org).

In addition to being a member of the Andean Community, Venezuela has bilateral trade agreements with Argentina, Brazil, and Paraguay. These agreements provide preferential tariffs for vegetable oils and oilseeds.

\section{Soybean Meal}

To meet the needs of the domestic animal feed industry, Venezuela imports most of its protein meals. The most popular product is soybean meal, and imports grew consistently during the late 1990s. Meal demand was expected to be hardest hit in 2003 because demand for pork and poultry has slumped due to lack of consumer purchasing power and price controls.

Meal imports were forecasted to decrease slightly in 2003, mainly due to a soybean meal and corn-mixing project to create a protein mix that would be exported to Colombia. Meal exports reflect the increase in that trade. Overall meal imports could increase significantly if the government removes the restrictions on foreign exchange and licensing since there is significant latent demand in the domestic industry.

Similar to the situation for soybeans, the United States has been replaced by Bolivia as the major supplier for soybean meal due to its preferential tariff arrangements under the Andean Pact.

\section{Soybean Oil}

To meet the needs of the domestic vegetable oil industry, Venezuela imports most of its soybean oils. Some South American countries (Bolivia, Paraguay, and Argentina) are the leading soybean oil suppliers.
Imports to Venezuela will continue since its domestic oil production is very small. Edible oil demand is expected to remain high, even in the face of price increases exceeding $150 \%$. The local industry uses a blend of $60 \%$ soybean oil plus sunflower seed, corn, sesame, or palm oil to manufacture local brands.

The United States has been replaced by Bolivia as the major supplier for soybean oil due to its preferential tariff arrangements under the Andean Pact.

\section{Red Meat}

While the market for imported red meats, mainly beef, is small in this beef-producing country, it has been steadily increasing. The majority is frozen, de-boned meat coming from Brazil and Colombia, but opportunities for high-end cuts of U.S. beef continue to gain more market share. Variety meats and trimmings make up the majority of the product mix coming into Venezuela. Fast-food chains are the main end-users for the product mix. At the retail level, beef is generally custom-cut for consumers at in-store butcher counters, although this trend is slowly changing. Most Venezuelans are accustomed to lean beef because Venezuelan cattle are generally grass-fed, but high-end consumers are always looking for something "unique" so grain-fed beef has great potential.

The import market for pork is very restricted as imports face various sanitary and tariff barriers. However, as the market for pork products grows, niche imports for certain cuts should become more available.

\section{Cereals / Mixes}

Imports of breakfast cereals and mixes (e.g., pancake mixes) have soared in the past two years reaching almost US\$15 million. The growth in this sector in 2002 was affected by the economic situation of the country. Half of these products are sourced out of Mexico, with the United States and Colombia as the other major suppliers. As more women enter the work force and households search for easier and quicker ways to prepare meals, we expect to see continued growth in this sector. Greater contact between buyers and sellers and more promotion 
efforts on the part of U.S. suppliers could elicit higher sales in this sector.

\section{Trade Regulations and Standards}

\section{Trade Barriers}

All imports are assessed a 1\% Customs handling charge. The import duties are calculated on the CIF value of the shipment. Venezuela has adopted the harmonized tariff schedule. Since 1995, Venezuela has generally adhered to the Andean Pact's Common External Tariff, which has four tariff levels: 5\%, $10 \%, 15 \%$, and $20 \%$.

Venezuela implemented the Andean Pact Price Band system for certain agricultural products (including wheat, grains, rice, pork, poultry, oilseeds, edible oils, oilseed meals, and milk) in April of 1995. This system tracks the estimated landed price of certain "marker" commodities. If marker prices fall outside the established price band, the ad valorem tariff for the marker product and the specified related products is adjusted upward or downward. Customs authorities have recently begun requesting the Venezuelan Certificate of Standards Compliance (COVENIN).

Venezuela has used its authority to issue sanitary and phytosanitary import permits to unfairly prohibit the importation of certain agricultural products (most notably fruit, poultry and pork), which compete with domestic products.

Almost all-agricultural imports must have sanitary or phytosanitary import certificates and a country of origin certificate, issued by the exporting country authorities, to be allowed entry. Medicines, foods, and cosmetics require registration with the Ministry of Health. Customs will admit products without a label showing the registration number if the importer produces the appropriate documentation from the relevant Ministry. Stickers are allowed and can be affixed on the retail package before distribution and sale.

In the case of imported alcoholic beverages, the tax "band" must be affixed across the bottle closure before the shipment can leave Customs. Imported cigarettes are also subject to this type of measure; adhesive labels are not allowed.

\section{Standards}

COVENIN (the Venezuelan standards agency) has established over 300 obligatory standards that apply to both domestic and imported products. These standards are not necessarily in conformity with or based on U.S. standards. In all cases involving products falling under such standards, Customs authorities require a Venezuelan certificate of compliance. The certificate can, on occasion, be obtained with a letter of certification confirming compliance, issued by a recognized standards institute in the country of origin. Importers have experienced some difficulty where no recognized foreign standards exist; Venezuela requires such a certificate of compliance. Exporters should consult with their customers, since it is the responsibility of the importer to provide such certificates.

For updates and clarifications of COVENIN standards, contact either the Foreign Commercial Service at the U.S. Embassy in Caracas or COVENIN.

\section{Labeling Requirements}

Spanish is the official language of Venezuela. The only official measuring system is metric. Labels must list all ingredients, the contents of the package in the metric system or in units, and the registration number of the Ministry of Health or the Ministry of Production and Commerce in the case of animal feeds or veterinary medicines. Almost all agricultural imports must have a certificate of origin from the country of origin issued by the exporting country authorities. Stickers are allowed in the case of imported products. These stickers must also identify the importer. Operating instructions or owner's manuals must be in Spanish.

\section{Temporary Entry Provisions}

Customs laws and regulations allow the import of merchandise on a temporary basis for exhibitions, cultural purposes, demonstrations, scientific purposes, or specific contracts. The importer must request permission for temporary entry, providing an exact description of the merchandise, its number or volume, its value, and its expected date of re-export. Temporary entry forms may be requested from the Gerente de Aduanas del SENIAT by phone (58 212) 
$274-4101 / 4508$ or by fax $(58212) 274-4128$. A reimbursable bond covering the full value of the duty, payable in case the product stays in the country, must be obtained (the bond fee will be returned once the product leaves the country). Normally, temporary entry permits are granted for a maximum stay of up to six months. The $1 \%$ Customs handling charge must be paid and is not reimbursable. In some cases, reimbursable collateral is requested for temporary imports.

Temporary entry of samples by visiting businessmen is allowed, but the determination of what is a sample is left to the Customs agent at the port or airport of entry. Samples arriving unaccompanied as freight are never considered as such, unless declared as having no commercial value and prepared in such a form that they cannot be sold commercially.

\section{Import Controls}

Many agricultural products still need import licenses, particularly those products that have tariff rate quotas that were negotiated when Venezuela joined the WTO. Venezuela has been slowly publishing its policies for the administration of these TRQs. In November of 1999, the government announced a list of prerequisites that must be completed prior to receipt of import licenses for certain commodities, including milk and milk products, cheese, corn, oilseeds and oilseed products, and sugar. Most significantly, the import licensing system often informally calls for purchasing of domestically produced commodities before granting licenses to importers. To obtain import licenses importers must:

- apply for an import license from the Ministry of Agriculture and Lands (MAT).

- provide MAT with proof of registration as a traditional importer.

- provide MAT with a record of all purchases of domestic production of the commodity listed during the last two years.

- obtain from MAT a certificate of domestic non-sufficient production.
- identify intended buyers if the commodity or its derived products are to be resold.

- provide MAT with a record of the volume of imports for the last two years.

Issuance of import licenses for many agricultural products has become increasingly nontransparent. The United States initiated formal WTO consultations with Venezuela in November of 2002 on its import-licensing regime. Argentina, Canada, Chile, Colombia, New Zealand, and the European Communities joined the United States in these consultations, which are ongoing. The United States also contends that Venezuela is restricting the issuance of Sanitary and Phytosanitary permits (SPS) for additional products.

Venezuelan Customs requires that all documents be in Spanish. The invoice must be a typewritten original; a photocopy will not be accepted. The manifest of importation and declaration of value must be in quadruplicate. The following documents may be required: commercial invoice; bill of lading; packing list; certificate of origin (if required); special certificates or permits, when required (e.g., phytosanitary or quality standards certificates or Ministry of Defense permit for firearms); and the pre-inspection certificate (Customs valuation).

It should be noted that freight handling in ports and airports is somewhat rudimentary and that damage might occur unless the products are well packed. If containers contain consolidated mixed cargo, Customs will separate their contents to check each single item.

The Importer's Registry was eliminated at the last quarter of 2000. All importers of agricultural commodities and by-products no longer must be registered at the Ministry of Production and Commerce (MPC), and do not need to demonstrate their importing history.

Pork from most countries is unofficially banned. Raw poultry from countries where Avian Influenza exists are banned. Products such as apples, pears, grapes, nectarines, and other fruits are unofficially banned at this time and are not included among the high priority products to receive dollars under the currency controls. 


\section{Export Controls}

In rare cases the government can apply controls. These are usually applied to avoid domestic shortages. Certain mineral resources are also subject to export controls. The re-export of capital goods is normally not allowed, unless the owner has made prior arrangements (before importing) to the effect that the equipment is to be used in Venezuela only for a specific project and will not stay in country.

Exporters should consult with the Venezuelan importer regarding what documentation is required in addition to the invoice.

\section{Free Trade Zones / Warehouses}

Venezuela has four free trade zones. The Paraguana Peninsula Free Trade Zone is for industrial purposes only, is very small, and is being used by only a few enterprises. Another is the duty-free area comprised of the entire island of Margarita; the sale of duty-free merchandise from the island to the mainland is subject to quotas. In December of 1998, Merida was declared a free trade zone to the producers of goods and services within the cultural, scientific, and technological areas. The most recent addition to the list is Santa Elena de Uairen in the State of Bolivar, which became a free trade zone in May of 1999.

Duty-free bonded warehouses are available at ports, airports, and in most major towns. Industrial establishments can be declared in-bond if used for assembly, completion, or improvement of products for re-export.

\section{Membership in Free Trade Agreements}

Venezuela is a member of the Andean Pact with Colombia, Ecuador, Bolivia, and Peru. Bilateral commerce with Colombia has increased substantially as a result of Venezuela's free trade agreement between the two. Relations are also expanding with Mexico and Colombia through the Group of Three Free Trade Agreement. Venezuela has partial free trade agreements with Chile and countries of Central America and CARICOM. Together with other Andean pact members, Venezuela is involved in the Free Trade Area of the Americas (FTAA) negotiations as well as other regional talks.

\section{Investment Climate in Brief}

- The government of Venezuela officially maintains a policy that promotes foreign investment to reactivate the economy. However, the exchange and price controls implemented in 2003, continued political uncertainty, and a negative economic environment have seriously hampered Venezuela's capacity to attract needed foreign investment.

- Decree 2095 significantly expanded foreign investment opportunities in Venezuela by lifting most restrictions on foreign participation in the economy. All sectors of the Venezuelan economy, except those specifically noted, are open to foreign participation. Article 13 of the Decree explicitly guarantees that foreign investors will have the same rights and obligations as national investors, except as provided for in special laws and limitations.

- Decree 2095 also guarantees foreign investors the right to repatriate $100 \%$ of profits and capital, including proceeds from the sale of shares or liquidation of the company, and allows for unrestricted reinvestment of profits.

- Decree 2095 reserves three areas of economic activity to national company television, newspaper, and professional services that are regulated by national laws.

- Foreign investors in capital markets and foreign direct investment projects are guaranteed the right to repatriate dividends and capital under the Constitution. However, the Law Governing the Foreign Exchange System permits the executive branch to intervene in the foreign exchange market "when national interests dictate".

- The Venezuelan government has recently been involved in at least two cases, which may yet result in expropriation claims, brought by U.S. companies.

- Venezuela's legal system is accessible to foreign entities seeking to resolve investment disputes. While the legal system is often slow, inefficient, and has been accused of corruption, 
foreign entities are not generally discriminated against in legal proceedings.

- Investment incentives take the form of tax credits, income and wholesale tax exemptions, exemption from Customs duties, and some tax rebates for selected sectors in the economy. Incentives to encourage production for the export market are available to both domestic and foreign companies.

- A bilateral treaty between the United States and Venezuela intended to prevent double taxation has been in effect since January of 2001.

- Access to the Venezuelan secondary capital market is relatively easy to obtain, and U.S. firms essentially enjoy national treatment. Foreign companies may issue common and preferred stocks, bonds, and other securities in Venezuelan capital markets. Foreign investors may also buy shares directly in national companies or on the stock exchange.

- More than 50 people have been killed in political clashes since April of 2002. Increasingly negative social and economic trends could again lead to violence.

- Corruption is a significant problem in Venezuela though the government has a regulatory system designed to prevent and prosecute corruption.

- The United States and Venezuela have been negotiating the terms for a bilateral investment treaty (BIT) for several years; no agreement has been reached.

- Venezuela participates in the Overseas Private Investment Corporation (OPIC) country program.

\section{Business Customs}

\section{Travel Advisory and Visas}

American travelers may obtain current information on crime, security, areas of instability, and other details pertaining to conditions in Venezuela by contacting the U.S. Department of
State's Bureau of Consular Affairs (telephone 202-647-5225; fax 202-647-3000; Internet http://travel.state.gov or http://embajadausa.org.ve ). We recommend that you thoroughly review the Consular Information Sheet for Venezuela before planning your travel.

To obtain a Venezuelan business visa you should contact the nearest Venezuelan Embassy or Consulate. Visitors with business visas are required to pay local income taxes if their stay in the country extends beyond 180 days.

All visitors are required to pay an airport departure exit tax of US $\$ 42.43$ (payable only in Bolivares) as of December of 2001. If traveling on a diplomatic passport, the departure tax is US\$30.31 (payable only in Bolivares).

\section{Business Infrastructure}

American companies interested in selling to the Venezuelan government should note that, according to Venezuelan law, all correspondence must be in Spanish. Companies that write to a government agency in English will probably not receive a reply. Government officials are not permitted to conduct official business in any language other than Spanish.

Venezuelan importers prefer to buy directly from the manufacturer instead of going through intermediaries. American exporters that are not manufacturers should try to associate themselves closely with the U.S. manufacturer, whenever possible.

Weekends and holidays are generally off-limits for business meetings with Venezuelans; these times are reserved for family. Christmas holidays last from December 15 through January 15 . No business travel should be attempted during this period.

Public transportation in Caracas consists of buses, the metro (subway), and taxis. Taxis are widely available in Caracas. Visitors should use licensed cabs belonging to established taxi lines. The airport taxi line uses black Ford Explorers only. Taxi service fees at hotels run about 50\% higher than street taxis. Several companies operate a radio-dispatched pick-up service. During the morning rush hour, at 
mid-day, and again in the early evening, it can be extremely difficult to find a taxi.

The Metro is open 5:30 a.m. to 11:00 p.m., Monday through Sunday, and offers an affordable, efficient alternative to taxis. Existing lines are limited, primarily running east to west through the city.

American airlines servicing Venezuela include American, Continental, and Delta. Many foreign airlines also serve Venezuela, most through Caracas, and a few through Maracaibo. Domestic flights are available to almost all-secondary cities of any size. Maiquetia, the international airport serving Caracas, is about 40 minutes from downtown. Expect to pay US $\$ 25$ to US\$30 in local currency for taxi service from Maiquetia to the city.

Local mail service is not dependable; important correspondence should not be sent by mail. International courier service should be used only for papers and documents (nothing else) or it will be delayed by Venezuelan customs. Most correspondence is done by fax or email. Messenger delivery is the best choice within Caracas and other large cities in lieu of the mail (for correspondence, invitations to receptions, etc).

There are only five "five-star" hotels in Caracas. Stars are awarded by the Venezuelan government, and do not correspond to any international standards. Four-star hotels are available at much lower rates, but service is at a lower standard, although budget-minded travelers will find many reasonable alternatives.

\section{Useful Web Sites}

\section{VENEZUELA:}

- Trade Venezuela http://www.trade-venezuela.com

- Chamber of Commerce (Venezuela) http://www.venamcham.org

- Latin Investor Venezuela Resources http://latinvestor.americaeconomia.com/country/ venezuela.htm
- Lanic Links-Venezuela

http://lanic.utexas.edu/la/venezuela

\section{UNITED STATES:}

- USDA Foreign Agricultural Service http://www.fas.usda.gov

- US Export Programs Guide http://infoserv2.ita.doc.gov/ticwebsite/tic.nsf/ AF34FA880278BDD5825690D00656C6F/ F69FDCF72B7713B58525691900746F18?Open Document

- Internet Guide to Trade Leads http://infoserv2.ita.doc/gov/ticwebsite/tic.nsf/ 504ca249c786e20f85256284006da7ab/ ef7db94aef24919885266470049c1cd?OpenDocu ment

- US Trade Finance Resources http://infoserv2.ita.doc.gov/ticwebsite/tic.nsf/ AF34FA880278BDD5825690D00656C6F/ F69FDCF72B7713B58525691900746F18?Open Document

- Basic Guide to Exporting http://www.unzco.com/basicguide/index.html

\section{HEMISPHERIC:}

- Hemispheric Guide on Customs Procedures http://alca-ftaa.iadb.org/hgcp_eng.htm

- Hemispheric Trade and Tariff Database http://alca-ftaa.iadb.org/eng/ngmadb_e.htm 